\title{
Political Education Through the Application of the Abstentions Countermeasure Model by KPUD (Regional Election Commission) Deli Serdang
}

\author{
Mohammad Yusri \\ Social Welfare \\ University of Muhammadiyah Sumatera Utara \\ Medan, Indonesia \\ mohd.yusri@umsu.ac.id
}

\author{
Dedi Amrizal \\ Public Administration \\ University of Muhammadiyah Sumatera Utara \\ Medan, Indonesia \\ dediamrizal@umsu.ac.id
}

\begin{abstract}
The implementation of the abstentions countermeasure model conducted by KPUD Deli Serdang can be an effective means of political education for the success of the general election in Deli Serdang. The objectives of this research are: 1) to investigate the effectiveness of the implementation of the new model carried out by KPUD Deli Serdang ; 2) to formulate the lack of application of model of abstentions countermeasure in Deli Serdang; 3) to prove that the new model of abstentions countermeasure can increase voter participation in general elections this year in Deli Serdang. This research is a descriptive study with a case study approach to prove the effectiveness of using abstentions countermeasure model. The results showed that the application of abstentions countermeasure model conducted by KPUD Deli Serdang was proven to be able to reduce the number of abstentions in the region. In addition, it was found that the implementation of the model was carried out in conjunction with the election smart home program. Political education is done naturally by involving community leaders and religious leaders. The application of this new model shows good results where public participation in elections is increasing and the number of abstentions is decreasing in Deli Serdang Distric However, the role of political parties has not been seen in the implementation of this abstentions countermeasure model

Keywords- political education, simultaneous local election, voter behaviour
\end{abstract}

\section{INTRODUCTION}

The first year of research carried out an ineffectiveness of the old model that only used socialization as a tool to cope with abstentions. Then in the second year of research a new model was obtained by including the components of community leaders, the Election Commission (through electoral smart houses) and elements of political parties. And in the third year, corrections were made to the participation of smart houses and political parties that were not optimal in political education. Political education through the abstentions countermeasure model was effectively carried out through socialization, public figures and maximum election house participation.

This third year research successfully implemented a new model and tested the effectiveness of the abstention prevention model (abstentions) in Regional Election Commission (KPUD) Deli Serdang. This is also evidenced by the increasing of people political participation in this 2019 general election. This means that in this 2019 general election, the number of abstentions in Deli Serdang is proven to decrease.

The strength of the issue and the emergence of voter awareness are the main causes of abstention. This can be expressed as a manifestation of the success of the abstentions countermeasure model implemented by KPUD Deli Serdang or others. In the first year of the study, it was found that socialization as the only way for political education to control abstentions by KPUD Langkat and KPUD Medan was less effective in increasing the number of voter participation.

This has encouraged the development of a new model to prevent abstentions from being applied by KPUD Langkat. In the second year of the study, abstentions countermeasure model was tested as a model although it did not work perfectly but showed results in voter participation. The role of Rumah Pintar Pemilu (the Smart House Election) and Community Leaders become very dominant compared to political parties. When all these components are combined with political socialization, this form of political education becomes very effective.

When the abstentions countermeasure model was applied in KPUD Langkat, it was seen that the process of implementing the program of Rumah Pintar Pemilu ( Smart House Election) had not been running optimally. The attention of KPUD Langkat is automatically focused on the election socialization as a form of political education to citizens. The implementation of the RPP has not been maximized due to funding problems and limited human resources. This complaint is attempted to be corrected in the application of the abstentions countermeasure model in the third year of the research carried out in KPUD Deli Serdang.

Political education efforts are carried out jointly between the General Election Commission, the Election Smart House and Community Leaders. KPUD Deliserdang works together with community leaders to disseminate information to the community by utilizing the RPP program by visiting the community directly in Deli Serdang. The implementation of political education is used as a conscious effort to change people's understanding of political values in accordance with 
the ideal political system expected by the government. Furthermore, with a good political education the government intentionally and systematically shaped its citizens into ethically and morally responsible societies in achieving political goals.

The abstentions countermeasure model offered in this third study can be carried out perfectly because the implementation of this research includes legislative and presidential elections. The participation of community leaders and the implementation of the RPP program must be in line in fostering citizens. The RPP program, which is usually carried out at the KPU office, is moved to places where citizens usually gather and are assisted by the active involvement of community leaders in each RPP program to provide political education to citizens.

In this third study, it appears that the model was implemented entirely by the Deli Serdang Regional Election Commission in conducting political education through socialization efforts, the implementation of the RPP program in collaboration with community leaders by visiting the communities where they are located. Fortunately, the application of this model was greatly helped by the very strong political issue of presidential elections which made the level of public participation in elections very high. to be better, this model can be tested again in normal situations without a central problem so that the effectiveness of the abstain prevention model can be seen clearly.

\section{METHOD}

The research method used is a qualitative descriptive method with a case study approach. The data extracted in this study is information about applying the right model in terms of overcoming abstention in elections. In addition, information from the Deli Serdang Election Commission, RPP and community leaders in implementing the new model was also explored. The data were obtained through observation, interviews and documentation studies. In this third year, the model is socialized and applied during the general election.

\section{FINDING AND DISCUSSION}

The testing of the abstentions countermeasure model basically wanted to prove the lack of socialization that had been carried out so far, then improvements and additions were made to create a model of abstention prevention and prove the increased level of participation in elections.

The following were some important things related to the management of population participation in Deli Serdang District:

\section{A. Political Education}

Political education is a conscious effort to change the process of political socialization of the community so that they understand and appreciate the values contained in the ideal political system to be built [1]. Meanwhile, political education is an intentional and systematic educational effort to form individuals to be able to become responsible participants ethically and morally in achieving political goals [2]. So, the form of political socialization conducted by the Election Commission so far has been developed more advanced by activating Rumah Pintar Pemilu (RPP)

\section{B. Political Socialization}

Socialization is basically a learning process for someone to understand and have an awareness of the role to act appropriately in society. According to Djuyandi, socialization is generally understood as a learning process. This condition occurs because basically people will never be satisfied to learn something that has not been known, such as learning about roles, norms and values to adapt with the social environment [3].

Election socialization includes formal socialization. According to Syarbaini, formal socialization, namely socialization carried out through authorized institutions according to state regulations or through institutions established according to applicable laws and government regulations [3]. While political socialization aims to provide political education. This is in line with the opinion of Prihatmoko, forming and fostering political personality and political awareness, as well as people's political participation [3].

\section{Political Participation}

Participation basically requires mental involvement or thoughts and emotions and feelings in an effort to achieve goals and also take responsibility for the efforts concerned. The involvement of individual citizens in political activities reaches various levels in the political system is called political participation [4].

Furthermore, political participation is an organized effort by citizens to elect their leaders and influence the form and course of public policy. This effort is based on awareness of their responsibility for shared life as a nation in a country [5]. In line with that, political participation is the activity of a person or group to actively participate in political life, such as by electing state leaders and directly influencing government policies [6].

Thus, political participation is the involvement of one's self, mental, mind and emotions or feelings from various levels of political activities such as election activities of state leaders through elections as a form of one's awareness and responsibility for government regulations or policies. Community participation in general elections is by participating in general elections to achieve the goals of nationhood and freedom in democracy. 


\section{Elections / Simultaneous Local Elections}

Based on the 1945 Constitution, the Republic of Indonesia is a state of sovereignty. General elections are a means to realize popular sovereignty in the framework of the participation of the people in the administration of the State government. The general election is not only aimed at choosing people's representatives who will sit in Consultative / Representative institutions, but also as a means to realize the governance of the State which is imbued with the spirit of Pancasila and the 1945 Constitution in the Unitary State of the Republic of Indonesia. So general elections are a means of implementing people's sovereignty in the unitary state of the Republic of Indonesia based on the Pancasila and 1945 Constitution.

In the general statement of UN human rights article 21 paragraph 1 , it is stated that every person has the right to take part in the government of his country, directly or through freely chosen representatives. The right to participate in this government is related and inseparable from the next right in paragraph 2, namely that every person has the right to obtain equal access to services by the government of his country.

In its implementation, the Deli Serdang Regional Election Commission always has an agenda for welcoming election events including; counseling, updating, technical guidance, socialization of the schedule for election, data collection and preparation of election sites. These things have been included in order to increase voter participation in one election period, both elections and regional elections.

This study tested the abstentions prevention model to prove some deficiencies in socialization such as limited time, human resources and residents encountered. This limitation required the improvement and addition of abstentions prevention components so as to create a model for the prevention of abstentions that included the importance of involving community leaders and political parties in the movement of electoral posts (RPP) built in the community. Finally, the last model that was proven by the increased level of participation in simultaneous regional elections was applied. The following was a discussion of research activities carried out:

\section{A. Political Socialization during Simultaneous Local Election}

Important activities that have a direct influence on the level of voter participation are the process of socialization the elections conducted by the Deli Serdang Election Commission. Socialization is one program in a series of general election activities. Election socialization has become the responsibility of the Deli Serdang Election Commission in accordance with the explanation in the General Election Commission Regulation Number 5 of 2015 concerning Public Information and Participation in the Election of Governors and Deputy Governors, Regents and Deputy Regents and / or Mayors and Deputy Mayor. Article 1 point 10 explains that the socialization of Election Implementation, hereinafter referred to as Election Socialization. Election Socialization is the process of delivering information about the stages and programs for holding elections.
The purpose of election socialization by the Deli Serdang Election Commission has been stipulated in KPU Regulation Number 5 Year 2015 article 3, namely: a) disseminating information about the stages, schedules and programs of the Election; b) increase public knowledge, understanding and awareness of rights and obligations in elections; and c) increasing voter participation in elections.

In the regulation mentioned about the target of election socialization in Article 4, namely: 1) the target in the implementation of Election Socialization, includes: a. general public; b. Beginner voters include teenagers, youth, students and university students; c. community leaders and / or traditional leaders; d. mass media group; e. political parties; f. supervisor, Domestic Election Monitor and Foreign Election Monitor; g. community organization; h. religious organization; i. indigenous groups; j. government agencies; k. political parties; and / or 1. Voters with special needs; 2) Voters with special needs as referred to in paragraph (1) letter 1 , include persons with disabilities, communities in border or remote areas, residents of prisons, patients and hospital workers, offshore mining workers, plantations, and other marginalized groups.

Article 9 of the regulation also mentions the method of socialization that can be carried out by the KPU through: (a) face-to-face communication; (b) mass media; (c) socialization material; (d) social mobilization; (e) utilization of local / traditional culture; (f) pages of the Provincial KIP / Aceh KIP and / or Regency / City KPU / KIP; (g) Aceh Provincial KIP / KIP announcement board and / or Regency / City KPU / KIP; (h) social media; (I) creation media; (J) other forms that make it easier for people to receive election information properly.

One of the objectives of the electoral socialization mentioned above is to increase voter participation in elections. Therefore socialization activities can increase voter participation. The success of socialization will determine the level of voter participation. Effective socialization will encourage the level of voter participation to be at the expected level. For this reason, effective election socialization is needed.

\section{B. Political Participation During Simultaneous Local Elections}

The election socialization conducted by the Deli Serdang Regency KPU included: a) cooperating with the PPK (SubDistrict Election Committee) and the PPS (Voting Committee) in the village and cooperating with the Population and Civil Registry Service in terms of providing electoral requirements, namely E-KTP based on Law Number 7 of 2017 concerning elections which states that the absolute requirement to be voters in elections is to have an Electronic Resident Identity Card (E-KTP); b) establishing billboards, banners, flayers, social media as a form of disseminating general election information to the public as a whole; c) socialization to high schools due to high school age is a prospective voter, so it was necessary to introduce direct elections, namely socialization carried out by conducting electoral simulations through the selection of Student Council guided by Deli Serdang Regency KPU; d) data collection on voter requirements. Record 
prospective voters in the village or sub-district; e) invited the community in the socialization activities conducted by the Deli Serdang Regency KPU. The effect of the socialization activities plus the training of leaders and the formation of local election posts was that the participation of citizens in voting increased..

\section{Political Participation during Simultaneous Local Elections}

The election socialization mentioned earlier is a program. In a program, the process of socializing or providing information and disseminating information about an activity is very necessary, as well as elections, socialization to the public about the implementation of the election needs to be done. An election dissemination activity also collaborates with supporting elements for the success of political development, the community and other agencies / organizations.

The effectiveness of a program is a condition that shows the level of success of an activity. The effectiveness of election socialization is the success rate of the socialization or dissemination of information programs on elections, based on procedures and objectives, through the use of resources, budgets, facilities and infrastructure, and integration (conducting socialization, consensus development and communication with various other organizations) to achieve organizational goals that have been consciously set beforehand.

Based on the description above, the effectiveness of election socialization can be measured. The effectiveness of election socialization can be said to be effective if through these variables; suitability of procedures, utilization of resources, budget, facilities and infrastructure, achievement of goals and integration (conducting socialization, consensus development and communication with various other organizations). The end of this is the increasing participation rate during simultaneous local elections and the decline in abstention rates in Deli Serdang Regency.

\section{CONCLUSION AND SUGGESTION}

The first study produced information about the ineffectiveness of the socialization carried out by the Langkat General Election Commission in dealing with abstention. This results in a more complete abstention prevention model to be able to overcome the weaknesses of the socialization that have been carried out by the Langkat General Election Commission. In this second study, a complete prevention model was applied to address the increasing number of abstentions in his regional elections. The third study maximizes the socialization role of the Deli Serdang Election Commission and the role of the RPP and community leaders.

\section{A. Conclusion}

Political education through the process of implementing the abstain prevention model is the first important thing that must be done to reduce the level of abstention that occurred in the legislative and presidential elections in Deli Serdang Regency this time.
After the election is complete, the number of abstentions has fallen, this shows that the abstention prevention model (abstentions) succeeded in carrying out political education to the residents of Deli Serdang. But the political issue of the presidential election is very strong also occurs in the community, so this model must still be tried again with a calm and safe political situation. In addition, political education through election socialization by the Election Commission is still very necessary and very effective when combined with the role of the RPP and community leaders. RPP and community leaders have an important role to educate the public directly related to the implementation of the election because it directly moves in the middle of the community.

The role of the Election Commission has been maximized in the application of the model by utilizing the RPP and community leaders who directly carry out political education in the midst of citizens who do not know and do not care so far.

The usefulness of the RPP at the KPUD office has made its political education role weak, through this research it is proven that the RPP assisted by community leaders succeeded in carrying out their duties while he was close to the community and mingled.

\section{B. Suggestion}

The implementation of political education through the RPP and community leaders and the Deli Serdang Election Commission through election socialization has been very effective in increasing voter participation and the quality of socialization. However, the condition of this study is influenced by political issues related to the issue of a very strong presidential election. For this reason, it is highly recommended that future researchers review this model in societies that are not affected by strong central issues. Political education carried out in the RPP program has not been well planned and its implementation has not been maximized. Therefore it is necessary to do further research that raises these problems.

\section{ACKNOWLEDGMENT}

This paper will not be completed without assistance from various parties. We are very grateful to the Directorate of Higher Education for funding this research. Thank also goes to the leadership of the Deli Serdang Election Commission who helped us implement the model and provided a lot of data in this study. Hopefully, this paper will be useful in assisting the Deli Serdang Election Commission, the central government and regional governments in reducing the number of abstentions.

\section{REFERENCES}

[1] Alfian, "Pemikiran dan Perubahan Politik Indonesia", Jakarta: Gramedia. 1981.

[2] Kartini Kartono, "Pendidikan Politik", Bandung: Mandar Maju, 1996.

[3] Dedi Amrizal, Yusriati Yusriati, dan Hermansyah Lubis, "The Role of General Election Commission (KPU) in Increasing Voters' Participation 
in Langkat, Medan, Indonesia”, BIRCI-Journal: Humanities and Social Sciences, e-ISSN: 2615-3076, p-ISSN: 2615-1715, Volume I, No 2 , June e 2018 pp. 16.

[4] Muhammad Arifin Nasution, "Role of Political Parties in Political Education and National Insight ", Politeia Journal ISSN: 0216-9290 Vol. 4 No.1, January 2012, pp. 35-40.
[5] Maran Rafcal Raga, "Pengantar Sosiologi Politik", Jakarta: Rineka Cipta. 2001.

[6] Miriam Budiardjo, "Dasar-Dasar Ilmu Politik", Jakarta: Gramedia Pustaka Utama, 2008. 